Review article

\title{
Modern trends in the care of seniors in the residential facilities of the social services
}

\author{
Dagmar Dvořáčková *, Adéla Mojžíšová \\ University of South Bohemia in České Budějovice, Faculty of Health and Social Sciences, Institute of Social and Special-paedagogical Sciences, \\ České Budějovice, Czech Republic
}

\begin{abstract}
The goal of this study is to map the current trends in the care of seniors in residential facilities of social services. This study is based on academic articles found in the SCOPUS and Web of Science databases between 2014 and 2018. The search criteria were focused on keywords (residential care, senior, trends) and areas (social work, social sciences, psychology, geriatrics, gerontology, health care and social services). We also used the web portals of the Ministry of Labour and Social Affairs of the Czech Republic and the Czech Statistical Office, the official web pages of residential social services for seniors and the academic references available in the Czech Republic in the last 10 years. The total number of sources used for this study was 48 . The results of the analysis show that the modern trends in the care of seniors in the residential facilities of social services are focused on various non-pharmacological approaches and very frequently connected to the total organization policy. The activities are related to the individual needs of seniors. The goal of these activities is preserving the seniors' independence for as long as possible, where dignity and autonomy are respected.
\end{abstract}

Keywords: Care; Residential services; Senior; Trend of care

\section{Introduction}

This study is based on the data analysis from academic articles found in the SCOPUS and the Web of Science databases between 2014 and 2018. The search criteria included keywords, such as residential care, senior or trends. 291 sources were found. Duplicate papers, papers focused on diagnostics, pharmacotherapy, toxicology and other medical areas were excluded. Other sources were the web portals of the Ministry of Labour and Social Affairs of the Czech Republic and the Czech Statistical Office, and the official web pages of residential social services for seniors and the academic references available in the Czech Republic from the last 10 years. The total number of sources used for this study was 48 .

\section{Population aging}

It is clear that, currently, the number of seniors is growing and such growth is shown in the population prognosis of the Czech Statistical Office by 2050. Great changes in the age structure will be reflected in the average age, which could be between 48 and 50 by 2050 , which is 10 years more than today (ČSÚ, 2004).

The population of the Czech Republic will evidently grow older. This trend will continue. The percentage of people over 65 years could approach one third in 2065, which would mean a doubling of the present percentage (ČSÚ, 2009). The number of people at the highest age will be the fastest to grow - the number of people over 85 is estimated to be 5 times higher by 2065 and, by the mid 21st century, every twentieth person will be 85 or older (ČSÚ, 2009).

The quality of life at old age can partially be affected by a long-term preparedness for old age. General knowledge about medicine and illness prevention is becoming continuously greater, so it is necessary to lead the society towards preparedness at middle age (Håvelsrud et al., 2014).

Active aging can be realized only if important life needs are satisfied and a quality and safe environment are ensured (Dvořáčková, 2014). Seniors are one of the endangered groups regarding the participation in society life and are threatened by social exclusion (Průša et al., 2015). The reasons can be a combination of different factors, such as health condition, low income, low education, the impossibility of commuting, unapproachable services, age discrimination, stereotypes at old age, etc. (Walsh et al., 2017).

The Ministry of Labour and Social Affairs of the Czech Republic issued a document called the National Programme of Preparing for Old Age, which focuses on the following areas: lifelong education, the employment of people at a higher age and seniors, voluntary work and inter-generation co-operation, a quality environment for seniors' life, healthy aging and care for seniors (MPSV, 2017a).

\footnotetext{
* Author for correspondence: Dagmar Dvořáčková, University of South Bohemia in České Budějovice, Faculty of Health and Social Sciences, Institute of Social and Special-paedagogical Sciences, Jírovcova 1347/24, 37004 České Budějovice, Czech Republic; e-mail: dvoracko@zsf.jcu.cz; http://doi.org/10.32725/kont.2018.002
} 


\section{Social exclusion at old age}

Some older people are threatened by social exclusion more than their peers. This fact is influenced by many internal and external factors (Patsios, 2014). Social exclusion is interconnected with satisfying seniors' needs (Dvořáčková, 2014). Seniors need to satisfy all their needs in life, just like anybody else, but they can be dependent on the help of others.

The need for care is not primarily associated with age but the decrease of functional abilities and self-sufficiency, which can limit a person in satisfying their everyday needs (Janečková, 2010). Insufficient or no satisfaction of some needs stops seniors from fully participating in society life, which increases the risk of social exclusion (Hsiao and Chen, 2018).

Loneliness and isolation in old age are associated with a worse health condition and may lead to serious health issues, such as depression, dementia, the decrease of functional abilities and even death (Glass and Vander Plaats, 2014).

Retirement can cause a reduction in seniors' social networks and they frequently live alone, which makes them lonely. They do not receive the necessary care and are socially isolated (Owari et al., 2018). Social exclusion has negative effects on public health as well (Glass, 2016). Burns et al. (2012) point out that, if the quality of life is not to be decreased, it is necessary to pay attention to lonely seniors, who can experience socioeconomic changes and social exclusion after they retire.

\section{Social support at old age}

Baker (2014) emphasizes the importance of social support for healthy aging and points out the risks associated with loneliness and isolation. This author encourages readers to include strong social relationships in the planning of their future and have friends in middle age. Building good family relationships and sufficient interests and hobbies are also very important.

Křivohlavý (2008a) defines social support as satisfying basic social needs through social interaction. He points out examples, such as the need for social contact, a friendly relationship, bonding, the need for solidarity, communication, social comparison, co-operation, social safety ensurance, social inclusion, a social identity or a positive social assessment.

Social support can have various forms. It can be received and provided. Nevertheless, it is certain that it has a different meaning for every person and a good family background is irreplaceable (Li et al., 2018). Close social relationships include intimacy and strengthen the feeling of belonging. They also bring assurance of one's own value, the feeling of safety and alliance. The availability and adequacy of social relationships also have their value in unfavourable situations (Schorr and Khalaila, 2018).

It is necessary to get acquainted with the social relationships of the person we are helping and the structure of social support, so that their needs are correctly diagnosed (Křivohlavý, 2008b).

Seniors with little social support feel emotionally lonely. They suffer from greater depressions and neuroticism (Schnittger et al., 2012).

Insufficient social support can cause social exclusion, especially when they become widows or widowers, their health condition worsens or they suffer from a chronic illness (Buffel et al., 2013).

\section{Residential facilities of the social services for seniors - the Czech Republic}

Lužný (2012) states that aging brings health problems as well as social and economic problems. This author points out that these issues are interconnected and they should not be sepa- rated. Social services for seniors are primarily focused on the development and preservation of independence and forestalling social isolation (MPSV, 2017b). Multidisciplinary teams in the facilities of social services focus on ensuring help in the care of one's self, and activate and support clients in all life areas, e.g. claiming their rights and promoting their interests (Chapman et al., 2018).

A typical residential facility in the Czech Republic is a senior home. Here, people with decreased self-sufficiency because of their age who require regular assistance are provided with help (MPSV, 2017b). Another facility for seniors is a special regime home. These homes are for people with decreased self-sufficiency because they suffer from a chronic mental illness or are addicted to substances. They also suffer from Alzheimer disease or other types of dementia (MPSV, 2017b). The regime in these facilities is adjusted to the specific needs of their residents. Another residential facility of the social services are homes for people with health impairment. They provide care to people with decreased self-sufficiency because of a health impairment (MPSV, 2017b). In one facility, the provider of social services can register more types of social services (Hrozenská and Dvořáčková, 2013).

Glass and Vander Plaats (2014) point out that aging in a community provides seniors with mutual support, increases the feeling of safety and inhibits social isolation.

\section{Modern trends in the care of seniors in residential facilities of the social services}

Currently, a great emphasis is put on the interconnection and openness of residential facilities regarding local communities and families, as well as the intergenerational coexistence (Železná, 2018). Social isolation is prevented and new relationships are built. Respecting human rights and the individual needs of social service users are of great importance (Dvořáčková, 2012). The facilities offer standard single and double rooms, various leisure activities, physical therapy and the possibility of using a chapel or any other spiritual support. If possible, the residents can use the garden, garden pergolas or winter gardens and terraces.

It is very important to use non-pharmacological methods in the care of seniors. In the 1980s, the validation therapy by Naomi Feil gained attention, especially regarding the work with seniors suffering from dementia (Malíková, 2011). Validation, after Naomi Feil, is a method which is globally used and recognized as a respectful way to communicate with seniors who are in various stages of dementia, and it is based on the general humanistic principles (Fertalová et al., 2017). It is a method of communication that claims to decrease stress, restlessness, crying and aggression, and positively affects the relationship between the carers and such seniors (Pokorná and Sukupová, 2014).

Another non-pharmacological treatment includes reminiscence therapy. It uses memories to help seniors to remember parts of their life and preserve their identity (Huldtgren et al., 2016). Reminiscence therapy is very convenient, easy to apply and cheap. It is good for patients with a mild and moderate dementia, as well as those where other therapies are not possible to apply (Holmerová et al., 2007). Work with memories helps the employees to understand their clients better, have a closer relationship with them and to plan meaningful services (Špatenková and Bolomská, 2011). The assets of the reminiscence therapy include non-invasive treatments, the prevention of mental illnesses, anxiety, depressions, the improvement of cognitive functions, self-esteem, satisfaction with life and personal interactions (Yen and Lin, 2018). The reminiscence ther- 
apy improves the communication of people with the syndrome of dementia as well (Mileski et al., 2018).

The narrative approach is also based on the work with memories. They are spontaneously told memories (life story - telling one's life story). The purpose of such storytelling is to fill the seniors' leisure time, ensure social inclusion, stimulate cognitive functions and strengthen self-esteem (Iannello et al., 2018). Janečková and Vacková (2010) point out that the participants of group narrative therapies progress in opening themselves to other participants in addition to the personnel. Knowing common fates and experiences positively affects the participants and evokes the need for support and respect (Janečková and Vacková, 2010).

According to Schwinghammer and Wehner (2013), activation of senses is a therapy that involves all senses in the activity, i.e. olfaction, sight, hearing, taste and touch. The authors of this study also point out the sixth sense, i.e. the perception of one's self in space. The result of such an approach is a complex cognitive, verbal and motoric activity. The authors also emphasize the supporting and exercising of sensory functions, which brings seniors pleasant feelings as well as a way of spending time. While exercising sensory functions, seniors are also physically active, which is positive for their self-sufficiency (Schwinghammer and Wehner, 2013).

Schwinghammer and Wehner (2013) state that a part of the activation of senses is also the pedagogy of Maria Montessori and her motto "Help me to do it by myself". They also point out the importance of the organization of daily activities and space, the use of materials, music or rituals that participants know well, and involving the participants in the planning of the activities. The activation of senses involves a number of other non-pharmacological approaches. The most common are memory training, environment therapy, art therapy, music therapy, kinesiotherapy or zootherapy (Janečková and Vacková, 2010).

Another approach used especially regarding seniors suffering from dementia is the concept of basal stimulation. It is a highly qualified set of therapeutic methods whose goal is to adjust the seniors' life situation and provide them with responding stimuli regarding cognitive, motoric and communication areas. Stimulation of individual senses evokes the stimulation of certain nerve complexes and strengthens the realization of one's body, its limits and one's self as well. The goal of basal stimulation in geriatric care is to keep seniors self-sufficient for the longest period possible, which positively affects the quality of their lives (Friedlová, 2012; 2014).

The knowledge of a senior's life story can contribute to better care. The best-known model of such care is the so-called psychobiographical model of care according to Böhm. Approximately 30 years ago, professor Böhm developed new approaches in geriatric care and biography as the basis for understanding other people and their behaviour (Böhm, 2016). He managed to activate (or reactivate) the lost abilities of elderly and confused people. This approach enabled those people to regain those abilities and apply them in everyday life (Procházková, 2014).

Memory training is one of the favourite activities of seniors, and not only regarding residential social services. Presently, there are a great number of manuals with memory training instructions and instructions for preserving the memory level or increasing it. Many literary references that help to achieve the effective absorption of information and the perfect use of memory are continuously becoming more popular among people.
Memory can be trained by using different methods, i.e. daily activities or supervised activities (Böhm, 2016). The brain needs stimulation and new experiences to be trained. New stimuli help the brain to create new nerve connections and increase its capacity (Procházková, 2014).

Memory training is an effective activation method that helps seniors to train their memory in an unforced way and to preserve and develop their abilities (Holczerová and Dvořáčková, 2013). We can assume that memory training and such brain activation can be positive for seniors and their environment as well (Buzan and Buzan, 2017). Healthy aging requires cognitive rehabilitation to become a part of daily life (Hohenfeld et al., 2017).

\section{Other activation activities used in the residential facilities of the social services}

There are various activation programmes in the residential facilities of the social services. They should be flexible in reflecting the abilities of their clients. The activation of seniors includes a meaningful and satisfying use of leisure time, and preserving and developing locomotive activities (Suchá and Jarolímová, 2017).

Each activity should be voluntary with a clear goal. It should be socially accepted and it should not lead to failure (Zokaei et al., 2017).

Such activities are, e.g., manual work (baking, cooking, making different things, etc.), music therapy, locomotion activities, dance therapy, art therapy, drama therapy, zootherapy, garden therapy, etc.

Whatever the activities are, they should always evoke joy in seniors. Holmerová (2014) states that senior age brings its limits, and the elderly should have the right to have their needs respected and to spend the rest of their lives in dignity.

\section{Conclusions}

A human is a bio-psycho-social and spiritual being. Life expectancy is becoming continuously longer and, therefore, the study of factors that significantly affect the quality of life at old age is becoming more important. If a senior cannot safely live in a home environment, they must make a difficult decision of whether to spend the rest of their life in a residential facility of the social services or not. In this new environment, they must adapt to its conditions and find new social contacts. They can be threatened by the loss of intimacy, the shock of adaptation and "the last stop syndrome". Senior homes and special regime homes are but one part in the care of seniors. These are designed for people with decreased self-sufficiency because of their age or health condition, chronic mental impairment or a type of dementia, i.e. their condition requires assistance.

The goal of this study is to map the contemporary trends in the care of seniors in the residential facilities of the social services. After analyzing the domestic and foreign sources, we learned that practice uses many models, approaches, methods and techniques. However, there is a disunity regarding terminology. Some activities are called therapies and others are called models or approaches. These activities are frequently associated with individual plans and included in the total organization approach and philosophy. Individual needs and human rights should always be respected.

In other countries, the association of a facility with the community is more emphasized. The Czech Republic is start- 
ing to develop activities that associate seniors in a residential facility with the close environment. An example can be the co-operation with children and students from different school types, volunteers, and family members, etc. It leads to natural intergenerational connection and prevents the social exclusion of seniors.

Modern trends in the care of seniors in the residential facilities of social care include a number of activities that are focused on an individual approach, and respect for individual personalities and their life stories. They also perceive the environment to be very important. The goal of these activities should be the longest possible preservation of self-sufficiency of seniors, where dignity and autonomy are respected.

\section{Conflict of interests}

The authors have no conflict of interests to disclose.

\section{Acknowledgements}

This article is financially supported by the TACR agency as part of the project No. TL 01000032 "Model of care for seniors in residential facilities in the concept of three-step housing".

\section{Moderní trendy péče v pobytových zařizeních sociálních služeb pro seniory}

\section{Souhrn}

Cílem této přehledové studie je zmapovat současné trendy péče o seniory v pobytových sociálních službách. V této studii jsme vycházely z aktuálních odborných článků uvedených v databázi SCOPUS a Web of Science v letech 2014-2018. Vyhledávací kritéria byla zaměřena zejména na klíčová slova (rezidenční péče, senior, trendy) a oblasti (sociální práce, sociální vědy, psychologie, geriatrie, gerontologie, zdravotní péče a sociální služby). V souvislosti s touto problematikou jsme vycházely také z webového portálu Ministerstva práce a sociálních věcí České republiky, webových stránek Českého statistického úřadu, oficiálních webových stránek pobytových sociálních služeb pro seniory a aktuální odborné literatury na českém trhu za posledních 10 let. Celkový počet zdrojů, které byly využity pro zpracování této studie, je 48 . Z výsledků naší analýzy vyplývá, že současné moderní trendy v péči o seniory $v$ pobytových sociálních službách jsou zaměřeny na různé nefarmakologické přístupy a často jsou propojeny s celkovou filozofií organizace. Spektrum činností se odvíjí od individuálních potřeb seniorů s ohledem na zachování lidských práv. Smyslem těchto aktivit je co nejdelší zachování soběstačnosti seniorů, a to s dưrazem na respektování důstojnosti a autonomie člověka.

Klíčová slova: senior; pobytové služby; trend; péče

\section{References}

1. Baker B (2014). With a little help from our friends: Creating community as we grow older. Vanderbilt University Press, $256 \mathrm{p}$.

2. Böhm E (2016). Psychobiografický model péče podle Böhma. Prague: Mladá fronta.

3. Buffel T, Phillipson C, Scharf T, 2013. Experiences of neighbourhood exclusion and inclusion among older people living in deprived inner-city areas in Belgium and England. Ageing and Society 33(1): 89-109. DOI: 10.1017/ S0144686X12000542.

4. Burns VF, Lavoie JP, Rose D (2012). Revisiting the role of neighbourhood change in social exclusion and inclusion of older people. J Aging Res 2012:148287. DOI: 10.1155/2014/148287.

5. Buzan T, Buzan B (2017). Myšlenkové mapy. Brno: BizBooks.

6. Chapman M, Lacey H, Jervis N (2018). Improving services for people with learning disabilities and dementia: Findings from a service evaluation exploring the perspectives of health and social care professionals. British Journal of Learning Disabilities 46(1): 33-44. DOI: 1010.1111/bld.12210.

7. ČSÚ (2004). Populační prognóza ČR do r. 2050. [online] [2018-06-04]. Available from: https://www.czso.cz/csu/czso/ populacni-prognoza-cr-do-r2050-n-g9kah2fe2x

8. ČSÚ (2009). Projekce obyvatelstva České republiky do roku 2065. [online] [cit. 2018-06-04]. Available from: https://www. czso.cz/csu/czso/projekce-obyvatelstva-ceske-republiky-doroku-2065-n-58t98jgowg

9. Dvořáčková D (2012). Kvalita života seniorů v domovech pro seniory. Prague: Grada.

10. Dvořáčková D (2014). Specifické faktory ovlivňující sociální exkluzi seniorů žijících v domácím prostředí. Aktuální otázky sociální politiky - Teorie a praxe, pp. 23 -37.

11. Fertal'ová T, Ondriová I, Majerníková L, Hadašová L (2017). Validation by Naomi Feil. Ceska a Slovenska Psychiatrie 113(4): 166-171.
12. Friedlová K (2014). Evidence Based Nursing - ošetřovatelství založené na důkazech. Odborný časopis Sociální služby XVI: 20-21.

13. Friedlová K (2012). Uplatnění konceptu Bazální stimulace v geriatrii. Prague: Mladá fronta, Sestra 22(9): 58-59.

14. Glass AP, Vander Plaats RS (2014). A conceptual model for aging better together intentionally. J Aging Stud 27(4): 428-442. 2014. DOI: 10.1016/j.jaging.2014.10.001.

15. Glass AP (2016). Resident-Managed Elder Intentional Neighborhoods: Do They Promote Social Resources for Older Adults? J Gerontol Soc Work 59(7-8): 554-571. DOI: 10.1080/01634372.2016.1246501.

16. Håvelsrud K, Thuve Dahm K, Sletsjøe H, Merete Reinar L (2014). The Effect of Activity in the Elderly. Oslo, Norway: Knowledge Centre for the Health Services at The Norwegian Institute of Public Health.

17. Hohenfeld C, Nellessen N, Dogan I, Kuhn H, Müller C, Papa F, et al. (2017). Cognitive Improvement and Brain Changes after Real-Time Functional MRI Neurofeedback Training in Healthy Elderly and Prodromal Alzheimer's Disease. Front Neurol 8(384). DOI: 10.3389/fneur.2017.00384.

18. Holczerová V, Dvořáčková D (2013). Volnočasové aktivity pro seniory. Prague: Grada.

19. Holmerová I, Jarolímová E, Suchá J (2007). Péče o pacienty s kognitivní poruchou. Prague: EV public, Gerontologické centrum.

20. Holmerová I (2014). Průvodce stříbrným věkem. Prague: Mladá fronta, $206 \mathrm{p}$.

21. Hrozenská M, Dvořáčková D (2013). Sociální péče o seniory. Prague, Grada.

22. Hsiao YC, Chen CY (2018). Exploring Individual, Family, and Extrafamilial Factors Associated With Depression Among Elderly Residents of Care Settings. Inter J Age Hum Dev 86(3): 219-241. DOI: 10.1177/0091415017699938.

23. Huldtgren A, Mertl F, Vormann A, Geiger C (2016). Reminiscence of people with dementia mediated by a tangible multimedia book. ICT4AWE - 2nd International Conference on 
Information and Communication Technologies for Ageing Well and e-Health, Proceedings, pp. 191-201.

24. Iannello P, Biassoni F, Bertola L, Antonietti A, Caserta VA, Panella L (2018). The Role of Autobiographical StoryTelling During Rehabilitation Among Hip-Fracture Geriatric Patients. Europ J Psychol 14(2): 424-443. DOI: 10.5964/ejop. v14i2.1559.

25. Janečková H, Vacková M (2010). Reminiscence. Prague: Portál.

26. Janečková H (2010). Sociální práce se starými lidmi. In: Matoušek O, Kodymová P, Koláčková J (Eds). Sociální práce v praxi: specifika vybraných cílových skupin a práce s nimi. Prague: Portál, pp. 163-194.

27. Křivohlavý J (2008a). Moderátor zvládání zátěže typu sociální opory. Československá psychologie.

28. Křivohlavý J (2008b). Psychologie zdraví. Prague: Portál.

29. Li XH, Wang B, Tan DX, Li M, Zhang D, Yan Y, et al (2018). Effectiveness of comprehensive social support interventions among elderly patients with tuberculosis in communities in China: a community-based trial. J Epidemiol Community Health 72(5): 369-375. DOI: 10.1136/jech-2017-209458.

30. Lužný J (2012). Gerontopsychiatrie. Prague: Triton.

31. Malíková E (2011). Péče o seniory v pobytových sociálních zařízeních. Prague: Grada, 328 p.

32. Mileski M, Topinka JB, Brooks M, Lonidier C, Linker K, Vander Veen K (2018). Sensory and memory stimulation as a means to care for individuals with dementia in long-term care facilities. Clin Interv Aging 13: 967-974. DOI: 10.2147/CIA.S153113.

33. MPSV (2017a). Národní program přípravy na stárnutí pro období let 2013-2017. [online] [cit. 2018-06-05]. Available from: https://www.mpsv.cz/files/clanky/13099/Teze_NS.pdf

34. MPSV (2017b). Sociální služby. [online] [cit. 2018-06-05]. Available from: https://www.mpsv.cz/cs/18661\#sszp

35. Owari Y, Miyatake N, Kataoka H (2018). Relationship between Social Participation, Physical Activity and Psychological Distress in Apparently Healthy Elderly People: A Pilot Study. Acta Med Okayama 72(1): 31-37. DOI: 10.18926/AMO/55660.

36. Patsios D (2014). Trends in older people's perceptions of necessities and deprivation in Great Britain and Northern
Ireland: what difference did a decade (or so) make? Journal of Poverty and Social Justice 22(3): 227-251.

37. Pokorná A, Sukupová M (2014). Naomi Feil validation in geriatric care. Kontakt 16(2): e71-e78. DOI: 10.1016/j. kontakt.2014.05.004.

38. Procházková E (2014). Práce s biografií a plány péče. Prague: Mladá fronta.

39. Průša L, Bareš $P$, Holub M, Šlapák M (2015). Vybrané aspekty péče o seniory z hlediska sociálního začleňování. Prague VÚPSV, v.v.i.

40. Schnittger RIB, Wherton J, Prendergast D, Lawlor BA (2012). Risk factors and mediating pathways of loneliness and social support in community-dwelling older adults. Aging Ment Health 16(3): 335-346. DOI: 10.1080/13607863.2011.629092.

41. Schorr AV, Khalaila R (2018). Aging in place and quality of life among the elderly in Europe: A moderated mediation model. Archiv Gerontol Geriatr 77: 196-204. DOI: 10.1016/j. archger.2018.04.009.

42. Schwinghammer Y, Wehner L (2013). Smyslová aktivizace: V péči o seniory a klienty s demencí. Prague: Grada.

43. Špatenková N, Bolomská B (2011). Reminiscenční terapie. Prague: Galén.

44. Suchá J, Jarolímová E (2017). Trénink paměti pro seniory. Prague: Edika.

45. Walsh K, Scharf T, Keating N (2017). Social exclusion of older persons: a scoping review and conceptual Framework. Eur J Ageing 14(1): 81-98.

46. Yen H-Y, Lin L-J (2018). A Systematic Review of Reminiscence Therapy for Older Adults in Taiwan. J Nurs Res 26(2): 138-150. DOI: 10.1097/jnr.0000000000000233.

47. Železná L (2018). Care-giving to grandchildren and elderly parents: role conflict or family solidarity? Ageing \& Society 38(5): 974-994. DOI: 10.1017/S0144686X16001434.

48. Zokaei N, MacKellar C, Čepukaityté G, Patai EZ, Nobre AC (2017). Cognitive Training in the Elderly: Bottlenecks and New Avenues. J Cogn Neurosci 29(9): 1473-1482. DOI: 10.1162/ jocn_a_01080. 